\title{
A Rise in Peripheral Melatonin Levels Induces Ovarian Activity in Anestrous Sheep
}

\author{
Yuji Mori, Kyoh Shimizu and Kunio Hoshino \\ Laboratory of Veterinary Reproduction, Tokyo University of Agriculture \\ and Technology, Saiwai-cho 3-5-8 Fuchu, Tokyo 183, Japan
}

(Accepted for publication July 17, 1987)

\begin{abstract}
Summary. Melatonin in Silastic capsules was implanted subcutaneously to examine the effect on reproductive activities of anestrous ewes under natural photoperiods. The constant supply of melatonin from the capsules increased plasma melatonin levels in a dose dependent manner, and high concentrations exceeding the endogenous night peaks were maintained throughout the day in the ewes carrying two capsules. On May 8 (Day 0) non-lactating ewes $(n=23)$ were divided into 3 groups, and were either implanted with one (MEL 1, $n=7$ ) or two (MEL 2, $n=6$ ) capsules, or left untreated (control, $n=10$ ). Plasma progesterone concentrations in the MEL 2 group rose and became significantly higher than those in the control group from Day 56 onwards. This suggests a stimulatory effect of melatonin on quiescent ovarian function. In the MEL 1 group, however, no apparent effect was observed, probably due to an insufficiency in basal melatonin elevation. These results suggest that the continuous presence of high melatonin levels in the circulation nullified the anti-gonadal effect of long days, presumably by blunting the endogenous rhythm of melatonin levels responsible for conveying information of the environmental photoperiod. KEY WORDS; MELATONIN, SHEEP, SEASONAL REPRODUCTION.
\end{abstract}

Jpn J Anim Reprod 33, 155-159, 1987

\section{Introduction}

It has long been recognized that out-of-seasonal reproductive activities can be induced in anestrous sheep by artificially reducing the daylength, i.e. by a short-day treatment (Yeates, 1949; Hafez, 1952). Recent studies have revealed that the pineal gland plays a key role in the photoperiodic control of reproduction in many seasonally breeding mammals including sheep (Lincoln \& Short, 1980; Karsch et al. 1984). Melatonin secretion by the pineal gland represents a distinct $24 \mathrm{hr}$ rhythm with the secretory phase being restricted to the dark period, and melatonin is therefore considered to be the hormone which conveys information on changing daylengths (Tamarkin et al., 1984).

Following those results, melatonin was administered to anestrous ewes either orally (Kennaway et al., 1982a; Arendt et al., 1983) or intramuscu- larly (Nett \& Niswender, 1982) at a fixed time in the afternoon, to simulate the short-day profiles of plasma melatonin. These treatments resulted in production of short-day responses with the onset of the breeding season. The efficacy of melatonin was thus demonstrated, but this method of timed melatonin administration for fairly long period is not very practical in terms of flock management.

The present study was therefore undertaken to examine whether the continuous administration of melatonin by means of subcutaneous implants, which is more convenient than the rhythmic administration, could also reactivate arrested gonadal function in anestrous ewes kept under long-day photoperiods.

\section{Materials and Methods}

Melatonin capsule: Subcutaneous capsules were constructed from 2 square Silastic sheets $(25 \times 50$ 
$\mathrm{mm}, 0.125 \mathrm{~mm}$ thick; Dow Corning, Midland, MI, USA), sealed on 4 sides with elastmer and containing $100 \mathrm{mg}$ of crystelline melatonin. Total surface area available for melatonin diffusion was $1200 \mathrm{~mm}^{2}$. In vitro tests showed that the capsule released 293.9 \pm 8.3 (mean \pm s.e., $\mathrm{n}=3$ ) $\mu \mathrm{g}$ melatonin per day into a buffered solution containing $1 \%$ albumin during 5 days incubation at $37^{\circ} \mathrm{C}$.

Diurnal profiles of plasma melatonin in ewes carrying melatonin capsules: Three female ewes weighing $31.6-44.0 \mathrm{~kg}$ were kept in the lightshield room of our laboratory under an artificial photoperiod with $14 \mathrm{hr}$ light (14L: 10D). The room was illuminated with fluorescent lights (approximately 400 lux at the height of ewes' heads during the light phase) with the continuous presence of red dim light (less than 1 lux) to facilitate blood sampling during the dark phase. Under sedation with xylazine the ewes were subcutaneously implanted at the axillary region with I melatonin capsule on Day 0 , and with an additional capsule on Day 8 . These implants were preincubated in sterilized saline solution $(0.87 \% \mathrm{NaCl})$ containing penicillin $(1000 \mathrm{IU} / \mathrm{ml})$ overnight to avoid a temporary release of large amount of melatonin following the subcutaneous insertions. To characterize the dirunal pattern of circulating melatonin, blood samples were collected from the jugular vein into a heparinized syringe at $2 \mathrm{hr}$ intervals over a $24 \mathrm{hr}$ period on Day -1 (before the implantation), Day 7 (when the ewes were carring 1 capsule) and Day 14 ( 2 capsules). The plasma was immediately separated and stored at $-20^{\circ} \mathrm{C}$ until assayed for melatonin by radioimmunoassay.

Effects of exogenous melatonin on ovarian function in anestrous ewes: Non-lactating crossbred (Corriedale $\times$ Suffolk) ewes $(n=23)$ kept in a commercial sheep ranch (Mother Farm, Chiba Prefecture, $35^{\circ} 15^{\prime} \mathrm{N}$ ) were randomly allocated to one of the following 3 groups on May 8, 1985 (Day 0): MEL 1 group; 7 ewes were implanted with 1 melatonin capsule as described above, MEL 2 group; 6 ewes were implanted with 2 melatonin capsules, control group; 4 ewes were implanted with an empty capsule and 6 ewes were left untreated. The average body weights on Day 0 were

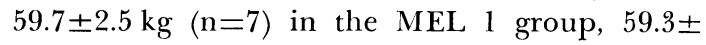
$2.3 \mathrm{~kg}(\mathrm{n}=6)$ in the MEL 2 group and $66.4 \pm 4.0 \mathrm{~kg}$ $(n=10)$ in the control group, with no significant differences among the groups. Thereafter, the 23 ewes were maintained together with 3 rams, under natural environmental light conditions. Blood samples were collected by venepuncture on Day 0 (before the treatment), Days 14, 28, and 45 and twice a week between Days 56 and 73. Plasma samples were separated by immediate centrifugation and kept below $10^{\circ} \mathrm{C}$ during the $3-5 \mathrm{hr}$ transfer to our laboratory. The plasma was then stored at $-20^{\circ} \mathrm{C}$ until assayed for progesterone concentrations.

Radioimmunoassays: Plasma melatonin was measured by the specific double-antibody radioimmunoassay described previously (Maeda et al. 1984; Mori \& Okamura, 1986). Two hundred $\mu \mathrm{l}$ of plasma was assayed in duplicate, and the limit of detection (95\% confidence limit of buffer control) was $25.0 \mathrm{pg} / \mathrm{ml}$. Intra- and inter-assay coefficients of variation were $16.2 \%(n=4)$ and $7.0 \%(n=4)$, respectively.

Plasma progesterone concentrations were assayed by the specific radioimmunoassay described elsewhere (Mori \& Kano, 1984). Two hundred $\mu \mathrm{l}$ of plasma was assayed in duplicate, and the limit of detection was $0.025 \mathrm{ng} / \mathrm{ml}$. Intra- and inter-assay coefficients of variation were $13.7 \%$ $(\mathrm{n}=4)$ and $8.4 \%(\mathrm{n}=5)$, respectively.

Statistical analysis: Results were expressed as mean \pm s.e. and Student's $t$ test was used to determine the significance of difference between group means.

\section{Results}

Figure 1 shows the diurnal patterns of plasma melatonin before and after melatonin implantation in 3 ewes kept under 14L:10D. Before the insertion of the subcutaneous capsules, plasma melatonin showed a distinct daily rhythm, with the secretory phase occurring at night. The mean plasma melatonin concentration during the light phase (05:00_19:00 hr) was $26.7 \pm 4.0 \mathrm{pg} / \mathrm{ml}$ (mean of 24 pooled samples from 3 ewes), while it was $127.3 \pm 24.7 \mathrm{pg} / \mathrm{ml}$ (mean of 15 pooled samples) during the dark phase (19:00-05:00 hr). The constant release of melatonin from the capsule increased the basal levels of circulating melatonin, on which endogenous night peaks were superimposed. Following s.c. insertion of 1 and 2 capsules, the daytime values of plasma melatonin 


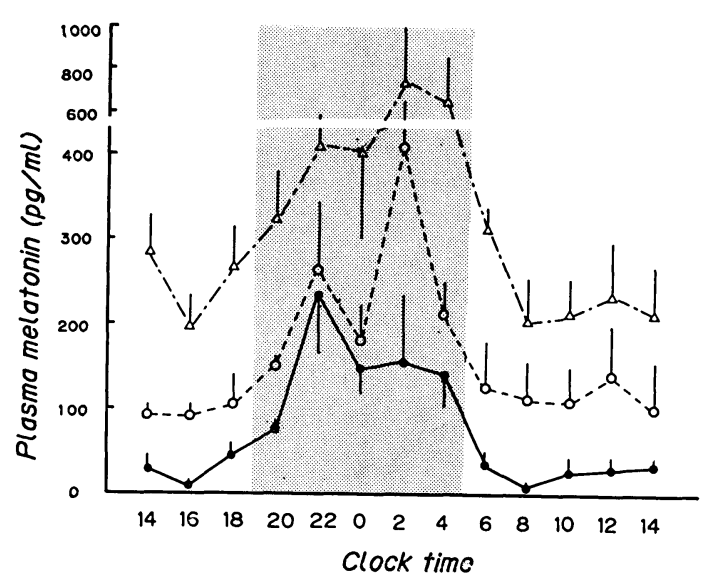

Fig. 1. Diurnal patterns of plasma melatonin in ewes $(n=3)$ carrying no $(\bullet)$, one $(\bigcirc)$ or two $(\triangle)$ subcutaneous melatonin capsules under 14L : 10D photoperiod. The shaded area represents the dark phase.

were elevated to $110.5 \pm 8.1 \mathrm{pg} / \mathrm{ml}$ and $241.2 \pm 15.7$ $\mathrm{pg} / \mathrm{ml}$, respectively. In the ewes carrying 2 melatonin capsules, plasma melatonin generally remained higher throughout the day than normal night peaks.

Figure 2 shows the mean plasma progesterone concentrations in the 3 groups of anestrous ewes treated with or without melatonin. On the treatment day (Day 0) plasma progesterone was lower than $1 \mathrm{ng} / \mathrm{ml}$ in all the 23 ewes, indicating the

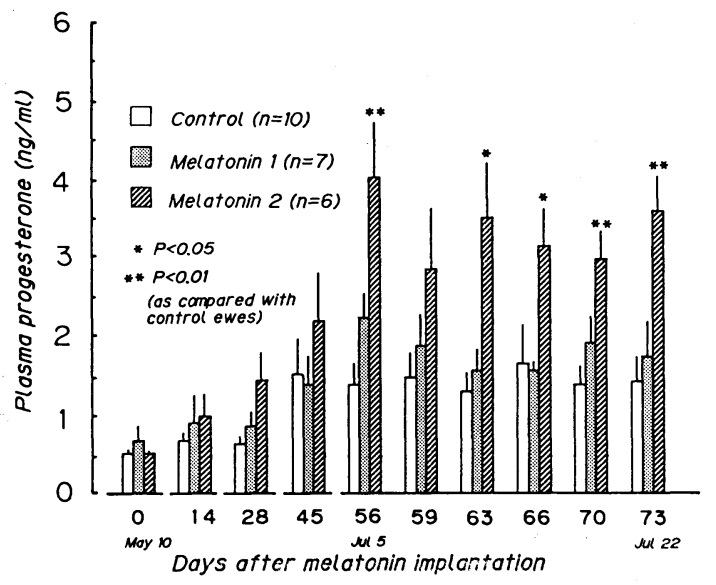

Fig. 2. Plasma progesterone concentrations in the three groups of anestrous ewes subcutaneously implanted with no (control), one or two melatonin capsules. absence of luteal function. In the MEL 2 group, progesterone levels gradually increased, and from Day 56 onwards (except for Day 59) they were significantly higher $(\mathrm{P}<0.05)$ than those in the control group. However, in the MEL 1 group, although plasma progesterone tended to stay higher than in the control, no appreciable difference was found between the 2 groups. In all the 3 groups, plasma progesterone exceeded $1 \mathrm{ng} / \mathrm{ml}$ after Day 45.

Plasma progesterone profiles in individual animals are schematically illustrated in Fig. 3. During the 16 days period between Days 56 and 73, in the number of ewes with functional corpora lutea, designated to have plasma progesterone levels higher than $2 \mathrm{ng} / \mathrm{ml}$ for at least 3 consecutive sampling times, i.e. 7 days or longer, there
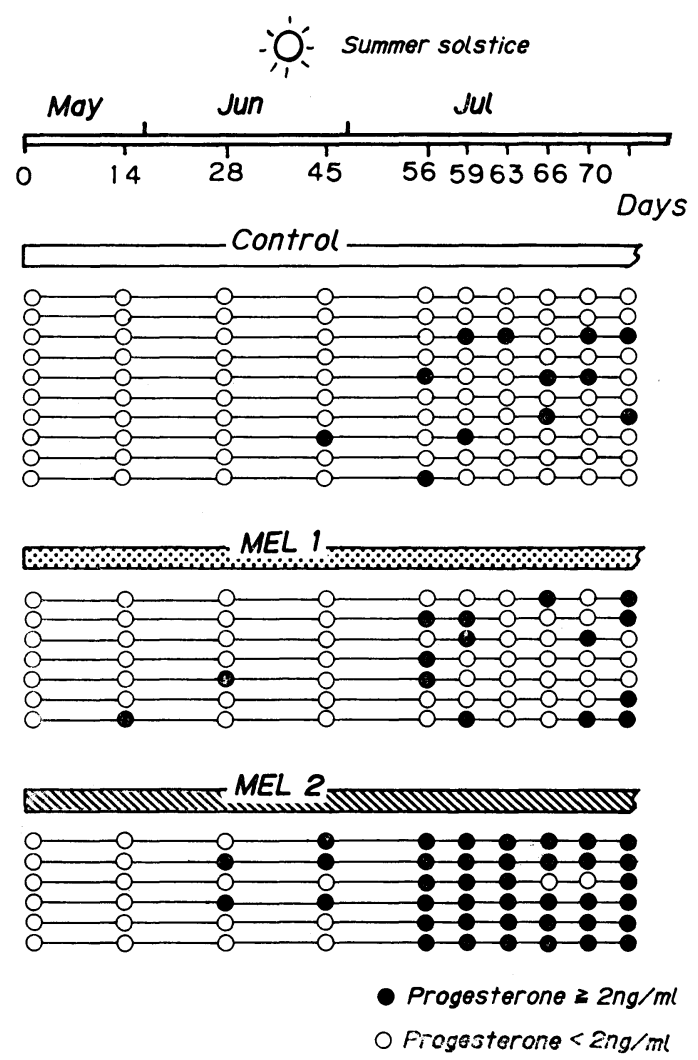

Fig. 3. Schematical illustration of plasma progesterone profiles in individual ewes carrying no (control, $n=10$ ), one (MEL 1, $n=7$ ) or two (MEL $2, n=6)$ melatonin capsules. Solid circles indicate sampling times when plasma progesterone exceeded $2 \mathrm{ng} / \mathrm{ml}$. 
was an apparent difference between the two groups: $6 / 6(100 \%)$ in the MEL 2 group vs. 0/6 $(0 \%)$ in the MEL 1 and the control groups.

Out-of-seasonal lambing was recorded between October and December. The average number of normal lambs (survived for a month or longer) per ewe was $1.0 \pm 0.36$, in the MEL 2 group, $0.43 \pm 0.2$ in the MEL 1 group and $0.2 \pm 0.13$ in the control group.

\section{Discussion}

Kennaway et al. (1982a), Nett \& Niswender (1982) and Arendt et al. (1983) independently found that daily melatonin administration either intramuscularly or orally, some hours before dusk reproduced the short-day profiles of plasma melatonin by elongating the duration of nocturnal rise. This induced precocious onset of reproductive activities in anestrous ewes kept under long days. Furthermore, timed melatonin infusion in pinealectomized ewes (Bittman et al., 1983; Bittman \& Karsch, 1984) or in pineal denervated goats (Mori \& Okamura, 1986) was also demonstrated to induce endocrine changes similar to those occurring in intact animals.

The results of the present study indicate that continuous administration of melatonin with s.c. implants is as effective in inducing short-day responses as those rhythmic ones. These results agree with the findings of recent studies on ewes treated with an intra-vaginal melatonin device (Nowak \& Rodway, 1985) and on ewes and rams carring s.c. implants (Kennaway et al., 1982b; Lincoln \& Ebling, 1985).

In female goats (Maeda et al., 1986) and rams (Almeida \& Lincoln, 1984), continuous secretion of melatonin being superimposed by nocturnal elevation has been demonstrated to accompany the reproductive photorefractoriness. After this the animals become tolerant to the anti-gonadal effect of long days, and thus spontaneously resume gonadal activities.

From these observations it appears quite plausible that a continuous increase of basal melatonin levels, which is either endogenous or exogenously induced, depresses or blindfolds the daily rhythm of melatonin secretion which has been conveying information on prevailing photoperiods. In other words, it is not necessary to simulate the short- day pattern.

The reason for no apparent effect in the ewe carrying 1 melatonin capsule would be due to an insufficiency in plasma melatonin rise. If this is the case, there should be a certain threshold level necessary for the plasma melatonin increase to completely mask the endogenous daily rhythm.

In conclusion, out-of-seasonal reproduction can be achieved by simply implanting ewes with s.c. melatonin capsules.

\section{Acknowledgments}

We wish to thank people in the Mother Farm, Futtsu City, Chiba Pref., for their cooperation and Drs. Y. Oikawa and J. Kohyama, Kimitsu Veterinary Clinical Center, Chiba P.F.A.M.A.A., for their technical help. We are also grateful to Dr. K. Kawashima for gifts of antiserum to melatonin, and to Dr. M. Takahashi for revision of original manuscript. This work was partly supported by a Grant-in-Aid for Scientific Research (61760278) from the Ministry of Education, Science and Culture, Japan.

\section{References}

Almeida OFX, Lincoln GA (1984) Reproductive photorefractoriness in rams and accompanying changes in the patterns of melatonin and prolactin secretion. Biol Reprod 30: 143-158.

Arendt J, Symons AM, Laud CA, Pryde SJ (1983) Melatonin can induce early onset of the breeding season in ewes. $J$ Endocr 97: 395-400.

Bittman EL, Karsch FJ (1984) Nightly duration of pineal melatonin secretion determines the reproductive response to inhibitory day length in the ewe. Biol Reprod 30: 585-593.

Bittman EL, Dempsey RJ, Karsch FJ (1983) Pineal melatonin secretion drives the reproductive response to daylength in the ewe. Endocrinology 113: 2276-2283.

Hafez ESE (1952) Studies on the breeding season and reproduction of the ewe. J Agric Sci, Camb 42: 189-265.

Karsch FJ, Bittman EL, Foster DL, Goodman RL, Legan SJ, Robinson JE (1984) Neuroendocrine basis of seasonal reproduction. Rec Prog Horm Res 40: 185-225.

Kennaway DJ, Gilmore TA, Seamark RF (1982a) Effect of melatonin feeding on serum prolactin and gonadotropin levels and the onset of seasonal estrous 
cyclicity in sheep. Endocrinology 110: 1766-1772.

Kennaway DJ, Gilmore TA, Seamark RF (1982b) Effects of melatonin implants on the circadian rhythm of plasma melatonin and prolactin in sheep. Endocrinology 110: 2186-2188.

Lincoln GA, Ebling FJP (1985) Effect of constantrelease implants of melatonin on seasonal cycles in reproduction, prolactin secretion and moulting in rams. $J$ Reprod Fert 73: 241-253.

Lincoln GA, Short RV (1980) Seasonal breeding: nature's contraceptive. Rec Prog Horm Res 36: 1-43.

Maeda K, Mori Y, Kano Y (1986) Superior cervical ganglionectomy prevents gonadal regression and increased plasma prolactin concentrations induced by long days in goats. J Endocr 110: 137-144.

Maeda K, Mori Y, Sawasaki T \& Kano Y (1984) Diurnal changes in peripheral melatonin concentration in goats and effects of light or dark interruption. Jpn J Vet Sci 46: 837-842.

Mori Y, Kano Y (1984) Changes in plasma concen- trations of $\mathrm{LH}$, progesterone and oestradiol in relation to the occurrence of luteolysis, oestrus and time of ovulation in the Shiba goat (Capra hircus). J Reprod Fert 72: 223-230.

Mori Y, Okamura H (1986) Effects of timed melatonin infusion on prolactin secretion in pineal denervated goat. J Pineal Res 3: 77-86.

Nett TM, Niswender GD (1982) Influence of exogenous melatonin on seasonality of reproduction in sheep. Theriogenology 17: 645-653.

Nowak R, Rodway RG (1985) Effect of intravaginal implants of melatonin on the onset of ovarian activity in adult and prepubertal ewes. $J$ Reprod Fert 74: 287-293.

Tamarkin L, Baird CJ, Almeida OFX (1985) Melatonin: a coordinating signal for mammalian reproduction? Science 227: 714-720.

Yeates NTM (1949) The breeding season of the sheep with particular reference to its modification by artificial means using light. J Agric Sci 39: 1-43.

\title{
メラトニンによるめん羊の季節外繁殖
}

\author{
森裕司・清水 恭・星野 邦夫 \\ 東京農工大学農学部獣医学科家畜臨床繁殖学教室
}

$$
\text { メラトニンをシリコンカプセルに封入して非繁殖期め }
$$
ん羊の腋下部皮下に埋み込み，繁殖活動に与える影響を 検討した。

$$
\text { カプセルからの持続的放出により, 血漿メラトニン濃 }
$$
度は用量反応的に上昇し，カプセル 2 個を持つ動物で は，暗期のピーク值に匹敵する高值が一日を通じて維持 された。

5 月 8 日 (Day 0)に, 非哺乳中の雌ヒツジ 23 頭を無作 為に 3 群に分け,メラトニンカプセルを 1 個 (MEL 1 群, 7 頭）または 2 個（MEL 2 群，6頭）埋め込み，ある
いは対照群 (10頭)として, 自然日長条件下で飼養した。 MEL 2 群では，血漿プロゲステロン濃度が上昇し， 処置開始約 2 力月後には対照群との間で有意差が生じ, 卵巣機能に対するメラトニンの促進的効果が示された。 一方，MEL 1群では，明瞭な効果が認められず，血中 メラトニン濃度の上昇が不十分であったためと推祭され た。

本実験の成績より，松果体ホルモンであるメラトニン の外生的投与によって, 短日処理と同様, 非繁殖期にめ ん羊の卵巣活動を誘起しうることが示された。 